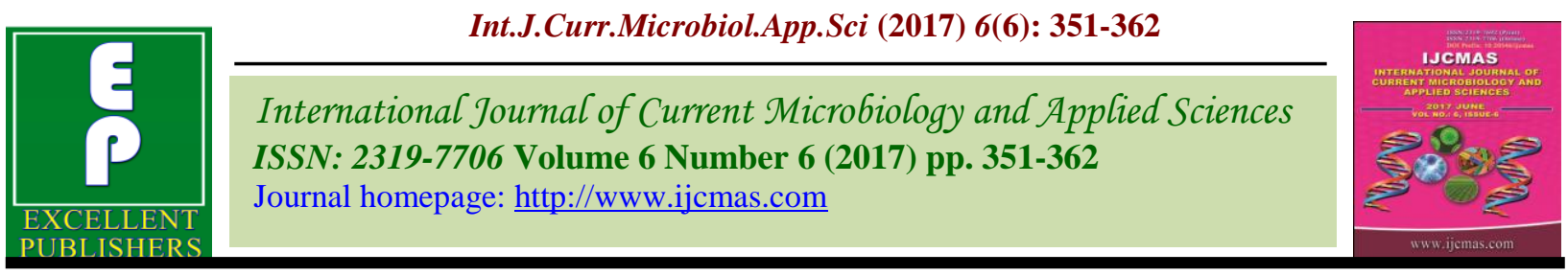

Original Research Article

https://doi.org/10.20546/ijcmas.2017.606.041

\title{
Temporal Changes in Biochemical and Antioxidant Enzymes Activities in Maize (Zea mays L.) under Waterlogging Stress during Early Growth Stage
}

\author{
Dinesh Kumar Yadav* and J.P. Srivastava \\ Department of Plant Physiology, Institute of Agricultural Sciences, \\ Banaras Hindu University, Varanasi-221005, UP, India \\ *Corresponding author
}

\begin{tabular}{|c|c|}
\hline & A B S T R A C T \\
\hline & $\begin{array}{l}\text { An experiment was conducted during kharif (rainy season) with two maize (Zea mays L.) } \\
\text { genotypes viz., CML-204 (waterlogging resistant) and HUZM-185 (waterlogging }\end{array}$ \\
\hline Keywords & $\begin{array}{l}\text { susceptible). Seeds were sown in plastic pots (size } 15 \times 15 \times 15 \mathrm{~cm} \text { ) having } 5 \mathrm{~kg} \text { pulverized } \\
\text { soil. Waterlogging stress was imposed at } 20 \text { days after sowing by placing plastic pots into }\end{array}$ \\
\hline $\begin{array}{l}\text { Antioxidant, } \\
\text { Superoxide }\end{array}$ & cemented container in such a way that the pots were fully submerged. Root samples were \\
\hline dismutase, & biochemical and antioxidant enzyme activities were analyzed. Waterlogging stress caused \\
\hline $\begin{array}{l}\text { Maize, } \\
\text { Hydrogen }\end{array}$ & reduction in soluble sugar and starch contents in both genotypes. Genotype CML-204 had \\
\hline Peroxide and & $\begin{array}{l}\text { ner soluble sugar content }(24.61 \mathrm{mg} g \\
\text { however, starch content was higher in HUZM-185 }\left(29.37 \mathrm{mg} \mathrm{g}^{-1} \mathrm{FW}\right) \text { than in CML-204), }\end{array}$ \\
\hline Waterlogging & $\left(22.73 \mathrm{mg} \mathrm{g}^{-1} \mathrm{FW}\right)$ at 6 days of waterlogging stress. Hydrogen peroxide content increased \\
\hline Stress. & in both genotypes and the magnitude was quite higher in HUZM-185 (1591.67 $\mu \mathrm{M} \mathrm{g}^{-1}$ \\
\hline Article Info & $\begin{array}{l}\left.\mathrm{FW}) \text { than the CML-204 (1510 } \mu \mathrm{M} \mathrm{g}^{-1} \mathrm{FW}\right) \text { at end of the stress. Peroxidase (POX) and } \\
\text { superoxide dismutase (SOD) activities were significantly higher in CML-204 than HUZM- }\end{array}$ \\
\hline $\begin{array}{l}\text { Accepted: } \\
\text { 04 May } 2017 \\
\text { Available Online: } \\
\text { 10 June } 2017\end{array}$ & $\begin{array}{l}\text { 185; however, polyphenol oxidase (PPO) activity was higher in HUZM-185 in } \\
\text { waterlogged plants. As compared to normal plants, waterlogging stress increased proline } \\
\text { content in both genotypes. Present investigation revealed that resistant genotype (CML- } \\
\text { 204) has greater potential to minimize the waterlogging stress damage by efficiently }\end{array}$ \\
\hline & $\begin{array}{l}\text { scavenging } \mathrm{H} 2 \mathrm{O} 2 \text { via intensifying antioxidant enzyme activities (POX, PPO and SOD) as } \\
\text { compared to susceptible genotype (HUZM-185). }\end{array}$ \\
\hline
\end{tabular}

\section{Introduction}

Maize (Zea mays L.) is an important cereal crop. It is grown in various agro-climatic conditions ranging from temperate to tropical. In northern India maize is mainly grown during kharif (July-October) which covers about $85 \%$ of the total area under maize cultivation. During kharif there is severe damage to crop due to waterlogging. The detrimental effects of waterlogging stress to plants is through reduction of oxygen concentration in the root zone i.e. hypoxia followed by anoxia which leads alteration in plant metabolic processes. The various physiological and biochemical responses of roots to anoxia may be related to the higher level of soluble sugars in the plant tissues. The level of soluble sugars in the plant system gives an indirect idea of metabolic status of the plant tissues as well as energy content of the plant (Srivastava et al., 2007). The reductions of oxygen concentration in the root zone results in oxidative stress and generates 
reactive oxygen species (ROS) disturbing various metabolic functions of plants (Ashraf, 2009; Ashraf et al., 2010). Under normal as well as in stress conditions, among the ROS, hydrogen peroxide $\left(\mathrm{H}_{2} \mathrm{O}_{2}\right)$ is the first stable compound produced within the plant cells. Deleterious ROS are include superoxide $\left(\mathrm{O}_{2}-\right)$, hydrogen peroxide $\left(\mathrm{H}_{2} \mathrm{O}_{2}\right)$ and the hydroxyl radical $(\bullet \mathrm{OH})$. These ROS are extremely reactive in the cell and provoke damage to various cellular metabolites such as proteins, lipids, DNA etc. (Ashraf, 2009). In the plant system the scavenging and detoxification of these ROS occurs through enzymatically and non-enzymatically. In the enzymatic defense system superoxide dismutase (SOD) constitute the first line of defense against ROS by dismutating $\mathrm{O}_{2}-$ into $\mathrm{H}_{2} \mathrm{O}_{2}$ which further catalyzed by $\mathrm{PPO}$ and POX which converts $\mathrm{H}_{2} \mathrm{O}_{2}$ into oxygen and water molecules.

Maize crop is very sensitive to waterlogging stress during early growth stages, thereafter sensitivity gradually decreases. Avoidance of waterlogging stress through tolerant genotypes, particularly at early growth stages, would be an ideal and affordable approach suitable for poor maize growing farmers in waterlogged areas. Hence, present investigation were made to examined the status of anaerobic compounds along with antioxidant enzyme activities in tolerant and susceptible maize genotypes under waterlogging stress at early growth stage which might be helpful for screening and avoidance of waterlogging stress with large number of genotypes of this crop.

\section{Materials and Methods}

\section{Plant material and waterlogging stress exposure}

Experiment was conducted with two screened maize genotypes viz., CML-204 (waterlogging resistant) and HUZM-185 (waterlogging susceptible). Seeds were procured from the Department of Genetics and Plant Breeding, Institute of Agricultural Sciences, Banaras Hindu University, Varanasi. Plants were grown in plastic pots (size $15 \times 15 \times 15 \mathrm{~cm}$ ) filled with $5 \mathrm{~kg}$ well mixed pulverized soil. Ten seeds were sown in each pot and 7 days after sowing thinning was done and five plants were maintained in each pot. Waterlogging stress was imposed at 20 days after sowing by putting pots into big sized cemented containers and water level was maintained $5 \mathrm{~cm}$ above the soil surface of the pots. Control plants were maintained with normal supply of moisture. Plants were uprooted and washed carefully to remove adhered material for collection of root sample at intervals of $0,1,2,3,4,5$ and 6 days after imposing waterlogging stress. Samples were immediately dipped in liquid nitrogen (-196 ${ }^{\circ} \mathrm{C}$ ) container. After $24 \mathrm{hrs}$, the samples were withdrawn from liquid nitrogen and stored in deep freezer at $-20^{\circ} \mathrm{C}$ for further biochemical and antioxidant enzymes analysis.

\section{Determination of soluble sugar and starch contents}

Soluble sugar and starch contents were determined by the method of Dubois et al (1956). For soluble sugar, $100 \mathrm{mg}$ root sample was homogenized with $5 \mathrm{~mL}$ of $80 \%$ ethanol and centrifuged at $4000 \mathrm{rpm}$ for $15 \mathrm{~min}$. Supernatant was collected and total volume was made up to $15 \mathrm{~mL}$ with $80 \%$ ethanol. Reaction mixture was prepared by adding 0.1 $\mathrm{mL}$ extract and $5 \mathrm{~mL}$ anthrone reagent and then boiled for $10 \mathrm{~min}$ after that cooled it in running tap water. A blank was also prepared in the similar way, but by taking $1.0 \mathrm{~mL}$ distilled water. The absorbance was measured at $620 \mathrm{~nm}$ by using spectrophotometer (ELICO SL-196). The amount of soluble sugar was calculated by using standard curve and expressed as mg g-1 fresh weight. 
Starch content was estimated from the residue obtained after extraction of soluble sugars by crushing sample with $6.5 \mathrm{~mL}$ of $52 \%$ perchloric acid and centrifuged at $10000 \mathrm{rpm}$ for $20 \mathrm{~min}$ at $0{ }^{\circ} \mathrm{C}$. Supernatant was collected and volume was made up to $20 \mathrm{~mL}$. Rest of the process was follows as in soluble sugar estimation.

\section{Estimation of hydrogen peroxide}

Hydrogen peroxide $\left(\mathrm{H}_{2} \mathrm{O}_{2}\right)$ content was estimated by using titanium reagent (Teranishi et al., 1974). Root sample (0.5 g) was grinded with $10 \mathrm{~mL}$ of cold acetone solution $(90 \% \mathrm{v} / \mathrm{v})$ and filtered. To the filtrate, $4 \mathrm{~mL}$ of titanium reagent was added followed by $5 \mathrm{~mL}$ of concentrated ammonia solution to precipitate the peroxide titanium complex and then centrifuged at $10,000 \mathrm{rpm}$ for $5 \mathrm{~min}$. Supernatant was discarded and precipitate was dissolved with $10 \mathrm{~mL}$ of $2 \mathrm{M} \mathrm{H}_{2} \mathrm{SO}_{4}$. It was re-centrifuged to remove undissolved materials and the absorbance of supernatant was recorded at $415 \mathrm{~nm}$ against blank by using spectrophotometer (ELICO SL-196). Hydrogen peroxide content was determined by using standard curve plotted with known concentration of $\mathrm{H}_{2} \mathrm{O}_{2}$.

\section{Antioxidant enzyme assays}

\section{Peroxidase and polyphenol oxidase}

Peroxidase (EC 1.11.1.7) and polyphenol oxidase (EC 1.14.18.1) activities were determined by the method of Kar and Mishra (1976). $100 \mathrm{mg}$ root sample was macerated with $5.0 \mathrm{~mL} 0.1 \mathrm{M}$ phosphate buffer ( $\mathrm{pH} 6.4$ ) and centrifuged at $10,000 \mathrm{rpm}$ for $20 \mathrm{~min}$ at $4^{\circ} \mathrm{C}$. Reaction mixture was prepared by adding $4.5 \mathrm{~mL} 0.1 \mathrm{M}$ phosphate buffer, 0.2 $\mathrm{mL}$ pyragallol and $0.1 \mathrm{~mL} \mathrm{H}_{2} \mathrm{O}_{2}$ and $0.2 \mathrm{~mL}$ supernatant. The mixture was incubated at $25^{\circ} \mathrm{C}$ for $5 \mathrm{~min}$. Thereafter, $0.5 \mathrm{~mL}$ of $5.0 \%$ $\mathrm{H}_{2} \mathrm{SO}_{4}$ was added to terminate the reaction.
Absorbance was recorded at $420 \mathrm{~nm}$ by using spectrophotometer (ELICO SL-196). Polyphenol oxidase activity was assayed in the similar way, with the deviation that $\mathrm{H} 2 \mathrm{O} 2$ was not added in the reaction mixture. Enzyme activities were expressed as units $\mathrm{g}^{-1}$ fresh weight $\min ^{-1}$.

\section{Superoxide dismutase}

Superoxide dismutase (EC 1.15.1.1) enzyme activity was estimated by the method of Dhindsa et al., (1981). $100 \mathrm{mg}$ root sample was crushed with $5 \mathrm{~mL}$ extraction buffer ( $0.1 \mathrm{M}$ phosphate buffer of $\mathrm{pH} 7.5$ containing $0.5 \mathrm{mM}$ EDTA) and centrifuged at 10,000 rpm for $10 \mathrm{~min}$ at $4^{\circ} \mathrm{C}$. Supernatant was collected and used as enzyme source. The three $\mathrm{mL}$ reaction mixture containing $0.1 \mathrm{~mL}$ of $1.5 \mathrm{M}$ sodium carbonate, $0.2 \mathrm{~mL}$ of 200 $\mathrm{mM}$ methionine, $0.1 \mathrm{~mL}$ of $2.25 \mathrm{mM}$ NBT, $0.1 \mathrm{~mL}$ of $3 \mathrm{mM}$ EDTA, $1.5 \mathrm{~mL}$ of $100 \mathrm{mM}$ potassium phosphate buffer, $1 \mathrm{~mL}$ of distilled water and $0.1 \mathrm{~mL}$ of enzyme extract were taken in test tubes in duplicate. Two tubes without enzyme extract were taken as control. The reaction was started by adding $0.1 \mathrm{~mL}$ riboflavin $(60 \mu \mathrm{M})$ and then tubes were placed below a light source of two $15 \mathrm{~W}$ florescent lamps for $15 \mathrm{~min}$. Reaction was stopped by switching off the light and covering the tubes by black cloth. Tubes without enzyme extract were developed maximum colour. A non irradiated complete mixture that did not develop colour served as blank. Absorbance was recorded at $560 \mathrm{~nm}$ by using spectrophotometer (ELICO SL-196). Enzyme units were calculated as follows:

Enzyme Units (EU) =

Enzyme*(light) - [Enzyme\#(light) -Enzyme* (dark)] Enzyme*(light)/2

Where, *without enzyme, \#with enzyme 


\section{Proline content}

Amount of proline was determined by the method of Bates et al (1973). $200 \mathrm{mg}$ root sample was homogenized with $5 \mathrm{~mL}$ of sulphosalicylic acid (3\%) and the supernatant was saved after centrifugation at $6000 \mathrm{rpm}$ for 10 min. Reaction mixture was prepared by adding $2 \mathrm{~mL}$ extract $+2 \mathrm{~mL}$ ninhydrin +2 $\mathrm{mL}$ glacial acetic acid. Thereafter, reaction mixture was placed in boiling water bath for $30 \mathrm{~min}$ and then cooled it followed by $5 \mathrm{~mL}$ toluene was added. Then solution mixture was shaken vigorously and toluene fraction was separated by separating funnel. The absorbance of toluene fraction was recorded at $520 \mathrm{~nm}$ with the help of spectrophotometer (ELICO, SL-196) against toluene blank. Concentration of proline was estimated by referring to a standard curve of proline.

\section{Statistical analysis}

Experimental data were recorded with average mean values for three replicates of each treatment and data were subjected to ANOVA for completely randomized design (CRD). Critical differences were taken at $\mathrm{p} \leq$ 0.05 .

\section{Results and Discussion}

\section{Soluble sugar and starch content}

Waterlogging stress decreased soluble sugar contents in both genotypes as compared to their respective normal plants (Table 1). The reduction in the soluble sugar content was recorded from starting (from 1st day) of waterlogging stress up to 3rd and 6th days in CML-204 and HUZM-185 respectively. The maximum reduction in the soluble sugar was recorded at 5th and 2nd days after waterlogging stress, while, it was minimum at 2nd and 1st days after waterlogging stress in both CML-204 and HUZM-185 genotype, respectively. Resistant genotype (CML-204) revealed moderately higher amount of soluble sugar than the sensitive genotype (HUZM$185)$ in response to waterlogging stress. Starch content was decreased in tolerant genotype, while there was fluctuation in sensitive genotype from 1st day to last day (6th day) of waterlogging stress (Table 2). The per cent reduction in starch content was more prominent in resistant genotype i.e., $173.60 \%$ at 3 rd day. However, in sensitive genotype it was $5.18 \%$ at 6th days after waterlogging stress. At end of the stress (6th day) sensitive genotype (HUZM-185) had higher amount of starch (29.37 $\left.\mathrm{mg} \mathrm{g}^{-1} \mathrm{FW}\right)$ as compared to the resistant genotype (CML204) which was $22.73 \mathrm{mg} \mathrm{g}^{-1} \mathrm{FW}$.

\section{Hydrogen peroxide content}

Waterlogging stress significantly enhanced the hydrogen peroxide $\left(\mathrm{H}_{2} \mathrm{O}_{2}\right)$ content, which continuously increased (from 1st days) with increasing in the waterlogging duration in both tolerant and sensitive genotypes (Table 3). However, tolerant (CML-204) genotype had lesser $\mathrm{H}_{2} \mathrm{O}_{2}$ content as compared to sensitive genotype (HUZM-185) in response to waterlogging stress. The per cent increment in $\mathrm{H}_{2} \mathrm{O}_{2}$ content in CML-204 was recorded from 4th day and it was continue increased up to 6th day, while in HUZM-185 the increment was observed from 1st day up to end of waterlogging stress (6th day). At end of waterlogging stress resistant genotype showed $1098 \mu \mathrm{M} \mathrm{g} \mathrm{g}^{-1}$ fresh weight $\mathrm{H}_{2} \mathrm{O}_{2}$ content whereas, sensitive genotype revealed 1591.67 $\mu \mathrm{M}$ g-1 fresh weight $\mathrm{H} 2 \mathrm{O} 2$ which was twofold greater from the beginning (1st day) of the waterlogging stress. Data were significant with treatment, genotype and duration of the stress along with their interactions at $\mathrm{p} \leq 0.05$.

Peroxidase, polyphenol oxidase and superoxide dismutase activities

Peroxidase activity (POX) gradually increased with increasing in the waterlogging 
duration in both CML-204 and HUZM-185 genotypes (Fig. 1). The maximum POX activity was recorded at 6th day i.e., 7.4 and 6.1 (units $\mathrm{g}^{-1} \mathrm{FW} \mathrm{min}^{-1}$ ) in both CML-204 and HUZM-185 genotypes, respectively, under waterlogged condition. Resistant genotype (CML-204) revealed higher POX activity as compared to sensitive genotype (HUZM-185) from beginning (1st day) to end (6th day) of the waterlogging stress. Genotype CML-204 acquired $12.52 \%$ increment in the POX activity, while it was $3.92 \%$ in HUZM-185 at 6th day of waterlogging stress.

Polyphenol oxidase (PPO) activity was slightly higher in resistant genotype as compared to sensitive under waterlogging stress. The increment in the PPO activity was observed from 4th day in resistant genotype, while in sensitive genotype from beginning (1st day) of the stress up to end (6th day) of the stress (Fig. 2). Polyphenol oxidase activity did not change significantly under waterlogging stress.

Waterlogging stress significantly increased superoxide dismutase (SOD) activity in both resistant and sensitive genotypes. The increment in the SOD activity was recorded from 1st day up to 6th day of waterlogging stress in both CML-204 and HUZM-185, however, resistant genotype revealed moderately higher SOD activity than the sensitive genotype (Fig. 3). At end (6th day) of the waterlogging stress resistant genotype acquired higher SOD activity i.e., 163.33 units g-1 FW $\mathrm{min}^{-1}$, while it was 111.00 units $\mathrm{g}^{-1} \mathrm{FW} \mathrm{min}^{-1}$ in sensitive genotype. Genotypic differences were significant at $p \leq 0.05$.

\section{Proline content}

When individual genotypes were examined, waterlogging stress significantly increased proline content in genotype CML-204; however it was significantly reduced in genotype HUZM-185 (Fig. 4). Resistant genotypes progressively increased proline content along with duration of waterlogging stress, the maximum concentration of proline (14.18\%) was observed at 6th day waterlogging stress. Whereas, in sensitive genotype proline content decreased from initial stage of waterlogging up to end (6th day) of the waterlogging stress and the maximum per cent reduction $(90.04 \%)$ was observed at 2 nd day and minimum (31.07\%) at 1st day of waterlogging stress.

\section{Soluble sugar and starch contents}

In the present investigation, soluble sugar was increased in resistant genotype (CML-204) under waterlogged condition as compared to the sensitive genotype (HUZM-185). On the other hand starch content was decreased, whereas, in sensitive genotype reduction in starch content was marginal under waterlogging stress. These results showed that the tolerant genotype is able to utilize stored starch anaerobically to maintain sufficient amount of soluble sugars, which is invariably required for respiration to providing metabolic energy under waterlogging stress and afterwards distressed situations. It was reported that, the level of soluble sugars in the plant system gives the metabolic status as well as the energy source of the plant tissue (Sairam et al., 2009; Srivastava et al., 2010). The increment in soluble sugar content was in 20 days old maize plants during initial period of waterlogging stress (Rai et al., 2004). Genotypes CML-204 contained significantly lower amount of starch than the HUZM-185 under waterlogged condition. Anoxia or submergence tolerance has in most cases been associated with a slower use of carbohydrates, rather than with their relative abundance (Banti et al., 2013) similarly, under waterlogging stress, a greater supply of sugars can be achieved through either increased synthesis or accelerate breakdown of stored starch in roots (Kulkarni and Chavan, 2013). 
Table.1 Temporal variations in soluble sugar content $\left(\mathrm{mg} \mathrm{g}^{-1}\right.$ fresh weight) in root of maize genotypes after imposing waterlogging stress

\begin{tabular}{|c|c|c|c|c|c|c|c|}
\hline \multirow{3}{*}{$\begin{array}{c}\text { Duration* } \\
\text { (in days) }\end{array}$} & \multicolumn{7}{|c|}{ GENOTYPE } \\
\hline & \multicolumn{4}{|c|}{ CML-204 } & \multicolumn{3}{|c|}{ HUZM-185 } \\
\hline & Normal & \multicolumn{2}{|c|}{ Waterlogged } & Mean & Normal & Waterlogged & Mean \\
\hline $\mathbf{0}$ & 25.32 & \multicolumn{2}{|c|}{$25.32(00)$} & 25.32 & 26.51 & $26.51(00)$ & 26.51 \\
\hline 1 & 23.3 & \multicolumn{2}{|c|}{$24.92(+6.50)$} & 24.11 & 30.98 & $24.73(-25.27)$ & 27.86 \\
\hline 2 & 22.21 & \multicolumn{2}{|c|}{$21.41(-3.74)$} & 21.81 & 31.92 & $20.00(-59.60)$ & 25.96 \\
\hline 3 & 35.87 & \multicolumn{2}{|c|}{$20.78(-72.62)$} & 28.33 & 30.93 & $20.60(-50.15)$ & 25.77 \\
\hline 4 & 36.44 & \multicolumn{2}{|c|}{$21.66(-68.24)$} & 29.05 & 28.94 & $20.90(-38.47)$ & 24.92 \\
\hline 5 & 40.23 & \multicolumn{2}{|c|}{$21.98(-83.03)$} & 31.11 & 29.72 & $20.70(-43.57)$ & 25.21 \\
\hline 6 & 44.09 & \multicolumn{2}{|c|}{$24.61(-79.15)$} & 34.35 & 30.62 & $20.47(-49.58)$ & 25.55 \\
\hline Mean & 32.49 & \multicolumn{2}{|c|}{22.95} & & 29.95 & 21.99 & \\
\hline \multicolumn{8}{|c|}{ ANOVA } \\
\hline Particulars & $\mathbf{W}$ & $\mathbf{G}$ & D & $\mathbf{W} \times \mathbf{G}$ & $\mathbf{W} \times \mathbf{D}$ & $\mathbf{G} \times \mathbf{D}$ & $\mathbf{W} \times \mathbf{G} \times \mathbf{D}$ \\
\hline SEm \pm & 0.22 & 0.22 & 0.41 & 0.31 & 0.59 & 0.59 & 0.83 \\
\hline CD at $5 \%$ & 0.63 & 0.63 & 1.17 & 0.89 & 1.66 & 1.66 & 2.35 \\
\hline
\end{tabular}

Where, N: Normal, W: Waterlogged, G: Genotype, D: Duration. * Waterlogging stress was imposed after 20 days of sowing. Values in the parenthesis are indicating percentage increase or decrease over normal.

Table.2 Temporal variations in starch content ( $\mathrm{mg} \mathrm{g}^{-1}$ fresh weight) in root of maize genotypes after imposing waterlogging stress

\begin{tabular}{|c|c|c|c|c|c|c|c|}
\hline \multirow{3}{*}{$\begin{array}{c}\text { Duration* } \\
\text { (in days) }\end{array}$} & \multicolumn{7}{|c|}{ GENOTYPE } \\
\hline & \multicolumn{4}{|c|}{ CML-204 } & \multicolumn{3}{|c|}{ HUZM-185 } \\
\hline & Normal & \multicolumn{2}{|c|}{ Waterlogged } & Mean & Normal & Waterlogged & Mean \\
\hline $\mathbf{0}$ & 24.35 & \multicolumn{2}{|c|}{$24.35(00)$} & 24.35 & 29.17 & $29.17(00)$ & 29.17 \\
\hline 1 & 38.33 & \multicolumn{2}{|c|}{$16.10(-138.07)$} & 27.22 & 30.70 & $32.77(+6.32)$ & 31.73 \\
\hline 2 & 49.56 & \multicolumn{2}{|c|}{$18.40(-169.35)$} & 33.98 & 31.55 & $32.87(-1.95)$ & 33.19 \\
\hline 3 & 49.33 & \multicolumn{2}{|c|}{$18.03(-173.60)$} & 33.68 & 27.87 & $33.87(+17.71)$ & 30.87 \\
\hline 4 & 50.92 & \multicolumn{2}{|c|}{$19.17(-165.62)$} & 35.05 & 26.86 & $27.17(+1.14)$ & 27.02 \\
\hline 5 & 50.13 & \multicolumn{2}{|c|}{$21.47(-133.49)$} & 35.80 & 28.33 & $28.60(+0.94)$ & 28.47 \\
\hline 6 & 52.38 & \multicolumn{2}{|c|}{$22.73(-130.44)$} & 37.56 & 30.89 & $29.37(-5.18)$ & 30.13 \\
\hline Mean & 45.00 & \multicolumn{2}{|c|}{20.04} & & 29.62 & 30.55 & \\
\hline \multicolumn{8}{|c|}{ ANOVA } \\
\hline Particulars & $\mathbf{W}$ & G & $\bar{D}$ & $\mathbf{W} \times \mathbf{G}$ & $\mathbf{W} \times \mathbf{D}$ & $\mathbf{G} \times \mathbf{D}$ & $\mathbf{W} \times \mathbf{G} \times \mathbf{D}$ \\
\hline SEm \pm & 0.34 & 0.34 & 0.63 & 0.48 & 0.89 & 0.89 & 1.26 \\
\hline CD at $5 \%$ & 0.95 & 0.95 & 1.78 & 1.35 & 2.52 & 2.52 & 3.56 \\
\hline
\end{tabular}

Where, N: Normal, W: Waterlogged, G: Genotype, D: Duration. * Waterlogging stress was imposed after 20 days of sowing. Values in the parenthesis are indicating percentage increase or decrease over normal. 
Table.3 Temporal variation in hydrogen peroxide content $\left(\mu \mathrm{M} \mathrm{g}^{-1}\right.$ fresh weight) in root of maize genotypes after imposing waterlogging stress

\begin{tabular}{|c|c|c|c|c|c|c|c|}
\hline \multirow{3}{*}{$\begin{array}{c}\text { Duration* } \\
\text { (in days) }\end{array}$} & \multicolumn{7}{|c|}{ GENOTYPE } \\
\hline & \multicolumn{4}{|c|}{ CML-204 } & \multicolumn{3}{|c|}{ HUZM-185 } \\
\hline & Normal & \multicolumn{2}{|c|}{ Waterlogged } & Mean & Normal & Waterlogged & Mean \\
\hline $\mathbf{0}$ & 1065.00 & \multicolumn{2}{|c|}{$1065.00(0.00)$} & 1065.00 & 690.00 & $690.00(0.00)$ & 690.00 \\
\hline 1 & 1005.00 & \multicolumn{2}{|c|}{$664.67(-51.20)$} & 834.83 & 530.00 & $768.00(+30.99)$ & 649.00 \\
\hline 2 & 870.00 & \multicolumn{2}{|c|}{$766.67(-13.48)$} & 818.33 & 545.00 & $803.33(+32.16)$ & 674.17 \\
\hline 3 & 850.00 & \multicolumn{2}{|c|}{$756.67(-12.33)$} & 803.33 & 640.00 & $1170.00(+45.30)$ & 905.00 \\
\hline 4 & 780.00 & \multicolumn{2}{|c|}{$786.67(+0.85)$} & 783.33 & 753.33 & $1400.00(+46.19)$ & 1076.67 \\
\hline 5 & 820.00 & \multicolumn{2}{|c|}{$1053.00(+22.13)$} & 936.50 & 761.67 & $1433.33(+46.86)$ & 1097.50 \\
\hline 6 & 853.33 & \multicolumn{2}{|c|}{$1098.00(+22.28)$} & 975.67 & 760.00 & $1591.67(+52.25)$ & 1175.83 \\
\hline Mean & 891.90 & \multicolumn{2}{|c|}{884.38} & & 668.57 & 1122.33 & \\
\hline \multicolumn{8}{|c|}{ ANOVA } \\
\hline Particulars & $\mathbf{W}$ & G & D & $\mathbf{W} \times \mathbf{G}$ & $\mathbf{W} \times \mathbf{D}$ & $\mathbf{G} \times \mathbf{D}$ & $\mathbf{W} \times \mathbf{G} \times \mathbf{D}$ \\
\hline SEm \pm & 9.33 & 9.33 & 17.45 & 13.19 & 24.68 & 24.68 & 34.90 \\
\hline CD at $5 \%$ & 26.43 & 26.43 & 49.44 & 37.37 & 69.92 & 69.92 & 98.88 \\
\hline
\end{tabular}

Where, N: Normal, W: Waterlogged, G: Genotype, D: Duration. * Waterlogging stress was imposed after 20 days of sowing. Values in the parenthesis are indicating percentage increase or decrease over normal.

Fig.1 Temporal variations in peroxidase activity $\left(\mathrm{EU} \mathrm{g} \mathrm{g}^{-1}\right.$ fresh weight $\left.\mathrm{min}^{-1}\right)$ in root of maize genotypes after imposing waterlogging stress

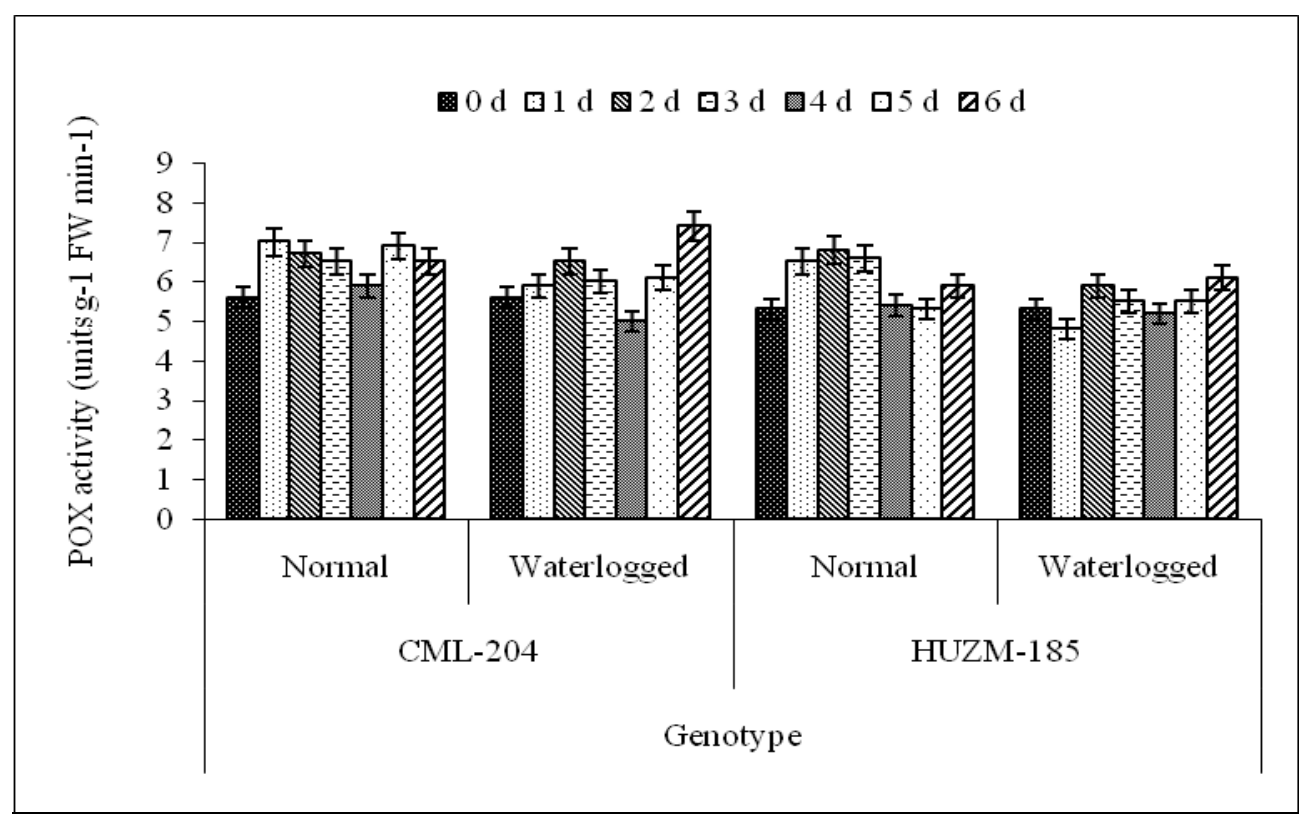

Where, d: waterlogging duration in days, Standard error bars are at 5\% level of significance 
Fig.2 Temporal variations in polyphenol oxidase activity (EU g $\mathrm{g}^{-1}$ fresh weight $\mathrm{min}^{-1}$ ) in root of maize genotypes after imposing waterlogging stress

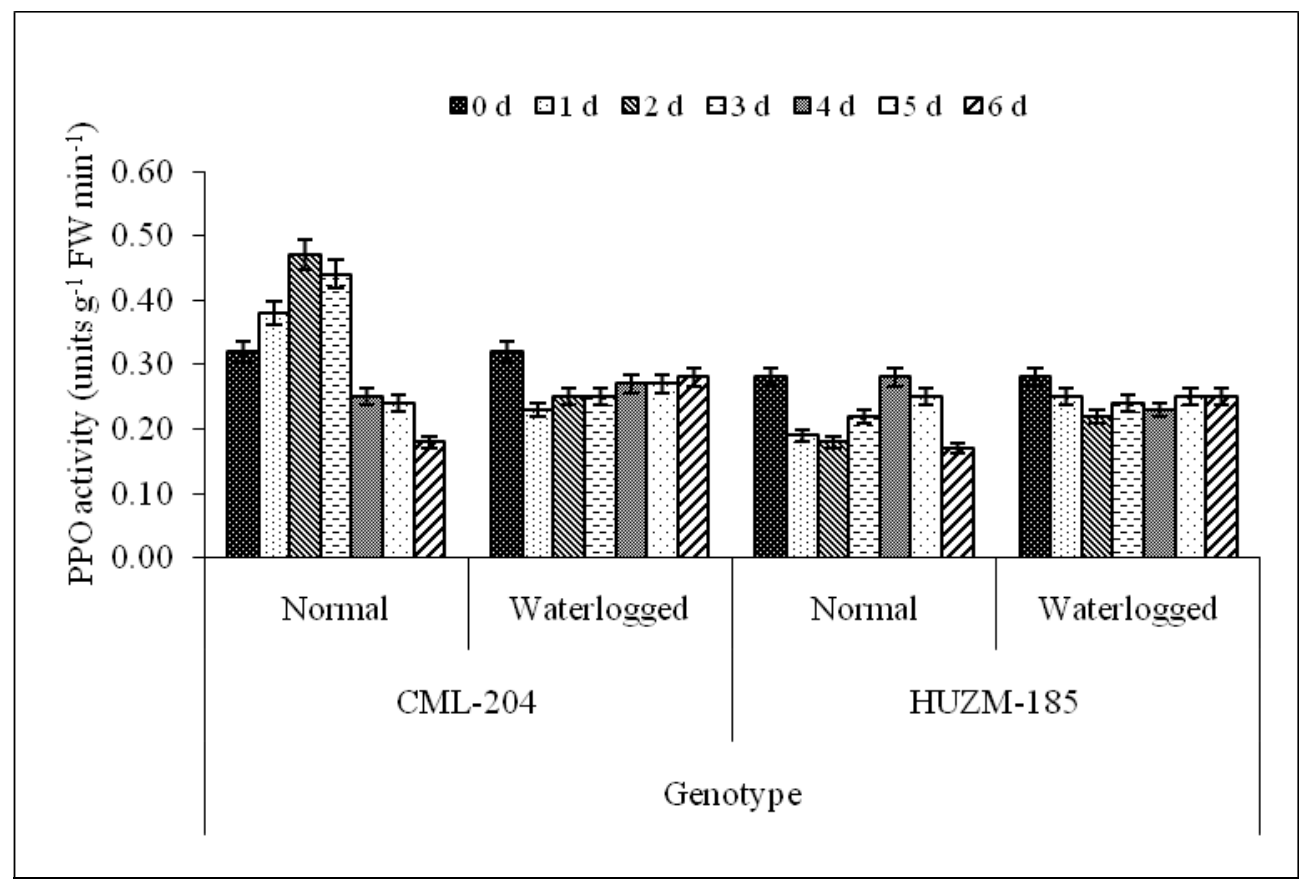

Where, d: waterlogging duration in days, Standard error bars are at 5\% level of significance

Fig.3 Temporal variations in superoxide dismutase activity (EU g ${ }^{-1}$ fresh weight) in root of maize genotypes after imposing waterlogging stress

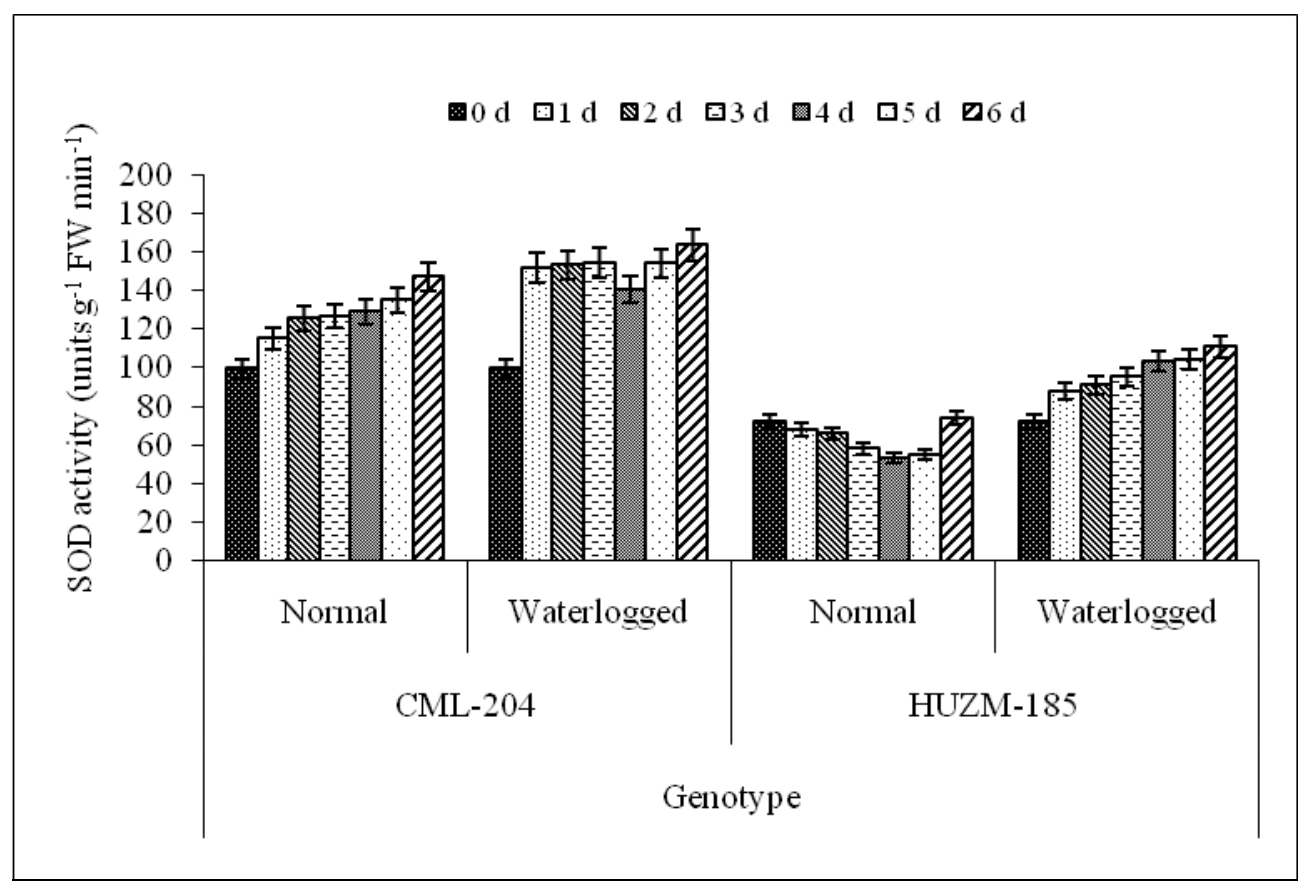

Where, d: waterlogging duration in days, Standard error bars are at 5\% level of significance 
Fig.4 Temporal variations in proline content $\left(\mu \mathrm{g} \mathrm{g}^{-1}\right.$ fresh weight) in root of maize genotypes after imposing waterlogging stress

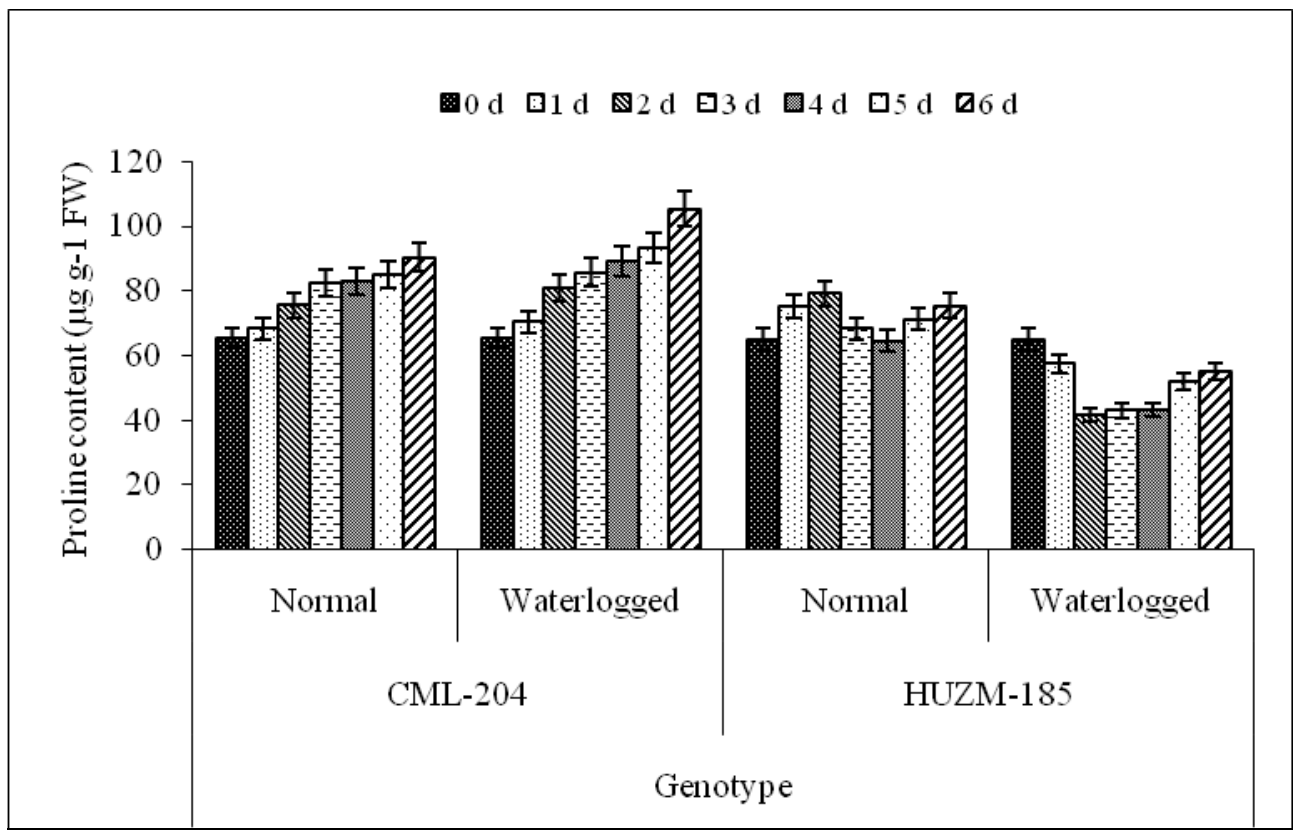

Where, d: waterlogging duration in days, Standard error bars are at $5 \%$ level of significance

\section{Hydrogen peroxide content}

Abiotic stresses caused excessive generation of reactive oxygen species (ROS) such as $\mathrm{H}_{2} \mathrm{O}_{2}$ etc. (Polle, 2001). These ROS are extremely reactive in nature and induce damage to a number of cellular molecules and metabolites (Ashraf, 2009). In the present study, the level of hydrogen peroxide $\left(\mathrm{H}_{2} \mathrm{O}_{2}\right)$ increased in both resistant and sensitive maize genotypes after imposing waterlogging stress, however, sensitive genotype revealed fairly higher $\mathrm{H}_{2} \mathrm{O}_{2}$ content under waterlogging stress condition. Similarly, in pigeonpea (Cajanus cajan Millsp.) genotypes waterlogging stress significantly enhanced the $\mathrm{H}_{2} \mathrm{O}_{2}$ content in sensitive genotype which was further increased with increasing in the waterlogging duration (Bansal and Srivastava, 2012). Higher $\mathrm{H}_{2} \mathrm{O}_{2}$ content in sensitive genotype might be responsible for its susceptibleness towards waterlogging stress. The accumulation of $\mathrm{H}_{2} \mathrm{O}_{2}$ was observed in waterlogged tomato, egg plants and in soybean (Alam et al., 2010). It is very important that $\mathrm{H}_{2} \mathrm{O}_{2}$ scavenging is more essential in imparting tolerance against waterlogging stress. Crops and their genotypes having better ability to detoxify reactive oxygen species, enzymatically (POX, PPO and SOD) or non-enzymatically (ascorbic acid, glutathione etc.), or those which are producing lesser amount of reactive oxygen species are reported to have resistance to waterlogging stress (Lin et al., 2004).

\section{Antioxidant enzyme activities}

Waterlogging tolerance might be achieved using several adaptive mechanisms and the modulation of antioxidative enzyme levels may be part of the whole mechanism. Peroxidase and polyphenol oxidase synthesis and accumulation in plants are mostly stimulated in response to biotic/abiotic stresses (Giorgi et al., 2009). Our study 
revealed that, both peroxidase (POX) and polyphenol oxidase activities increased in resistant genotype (CML-204) as compared to sensitive genotype (HUZM-185) in response to waterlogging stress. POX and PPO enzymes are responsible for scavenging of $\mathrm{H}_{2} \mathrm{O}_{2}$ produced under oxidative stress; therefore, these enzymes removed the excess $\mathrm{H}_{2} \mathrm{O}_{2}$ more efficiently in resistant genotype and conferred resistance against waterlogging stress. The POX activity was also increased in wheat under waterlogging stress (Tan et al., 2008). Tang et al (2010) reported that the activity of POX was increased in maize genotype after 4th to 6th day of waterlogging stress as compared to their control plants. Bansal and Srivastava (2012) confirmed that, PPO activity was increased as a consequence of waterlogging stress and was $487.2 \%$ higher in ICPL-84023 (tolerant), while it was $444.2 \%$ in MAL-18 (susceptible) pigeonpea genotype.

Superoxide dismutase is the ubiquitous enzyme and considered as first line of defense against oxidative stress by converting superoxide $\left(\mathrm{O}_{2}^{-}\right)$into hydrogen peroxide $\left(\mathrm{H}_{2} \mathrm{O}_{2}\right)$. In the present investigation, the SOD activity was increased by waterlogging stress in both resistant and sensitive genotypes, however, resistant genotype (CML-204) acquired moderately higher SOD activity as compared to the sensitive genotype (HUZM185). Increase in SOD activity was also reported in citrus (Hossain et al., 2009), maize (Tang et al., 2010) and pigeonpea [Kumutha et al., 2009; Singh, 2010) during waterlogging stress. In vitro condition grown rice seedlings also exhibits the SOD activity under abiotic stress (Thamodharan and Arumugam Pillai, 2014). These information clearly indicating that when plants are exposed to waterlogging stress utilize antioxidant defense system to get through the detrimental effects of oxidative stress induced by ROS, particularly in resistant genotype.

\section{Proline content}

Waterlogging stress affects physiological processes in pigeonpea genotypes which are related to the growth and development (Kailash et al., 2014). Under waterlogged condition, tolerant maize genotype showed greater amount of proline, whereas, it was decreased in sensitive genotype. Increased level of proline under waterlogged condition, as compared to normal plants, in genotype CML-204 might be associated with its waterlogging resistant characteristics. The adaptation process of crops to adverse environmental stresses is often accompanied by changes of some compatible osmolytes (Ou et al., 2011). It is well known that abiotic stresses result in increased proline contents in plants (Srivastava et al., 2007). Under waterlogging stress, proline contents of leaves increased significantly in sesames (Xu et al., 2012). Arbona et al., (2008) reported that higher amount of proline in plants have been found to be linked with increase in tolerance to oxidative damage under stress.

In conclusion, tolerant maize genotype (CML-204) had higher amount of soluble sugar and proline content. Soluble sugars are direct source of energy to resistant genotype by hydrolyzing starch reserves present in the plants, while proline maintains the osmotic balance under waterlogging stress. Sensitive genotype (HUZM-185) accumulated greater hydrogen peroxide content than the resistant genotype under waterlogging stress. Consequently, hydrogen peroxide, an ROS, is directly associated with lipid peroxidation leading to oxidative damage during waterlogging stress in sensitive genotype which alters the various metabolic processes of the plant and finally affects the crop growth and development. Waterlogging resistant genotype exhibited higher POX, PPO and SOD activities as compared to sensitive genotype under waterlogging stress. 
Higher antioxidant potential in CML-204 (resistant genotype) as evidenced through increased capacity for ROS $\left(\mathrm{H}_{2} \mathrm{O}_{2}\right)$ scavenging and indicated strong relationship between waterlogging resistance and antioxidant defense system in maize.

\section{Acknowledgments}

This work is supported by the Department of Plant Physiology, Institute of Agricultural Sciences, Banaras Hindu University, Varanasi-221005.

\section{References}

Alam, I., Lee, D., Kim, K., Park, C., Sharmin, S. A., Lee, H., Oh, K., Yun, B. and Lee, B. 2010. Proteome analysis of soybean roots under waterlogging stress at an early vegetative stage. J. Biol. Sci., 35(1): 4962.

Arbona, V., Hossain, Z., Lopez-Climent, M. F., Perez-Clemente, R. M. and GomezCadenas, A. 2008. Antioxidant enzymatic activity is linked to waterlogging stress tolerance in citrus. Physiol. Planta., 132: 452-466.

Ashraf, M. 2009. Biotechnological approach of improving plant salt tolerance using antioxidants as markers. Biotech. Advances, 27: 84-93.

Ashraf, M. A., Ashraf, M. and Ali, Q. 2010. Response of two genetically diverse wheat cultivars to salt stress at different growth stages: Leaf lipid peroxidation and phenolic contents. Pakistan J. Bot., 42: 559-565.

Bansal, R. and Srivastava, J. P. 2012. Antioxidative defense system in pigeonpea roots under waterlogging stress. Acta Physiol. Plant, 34: 515-522.

Banti, V., Beatrice, G., Silvia, G., Elena, L., Leonardo, M., Giacomo, N., Eleonora, P., Sandro, P., Chiara, P., Antonietta, S. and Pierdomenico, P. 2013. Low oxygen response mechanisms in green organisms. Int. J. Mol. Sci., 14: 4734-4761.
Bates, L. S., Waldeen, R. P. and Teale, I. D. 1973. Rapid determination of free proline for water stress studies. Plant Cell 39:205-208.

Dhindsa, R. A., Plumb-Dhindsa, P. and Thrope, T. A. 1981. Leaf senescence Correlated with increased permeability and lipid peroxidation and decreased levels of superoxide dimutase and catalase. J. Exp. Bot., 126: 93-101.

Dubois, M., Gilles, K. A., Hamilton, J. K. and Smith, F. 1956. Colorimetric method of determination of sugar and related substance. Ann. Chem., 28: 350-356.

Giorgi, A., Mingozzi, M., Madeo, M., Speranza, G. and Cocucci, M. 2009. Effect of nitrogen starvation on the phenolic metabolism and antioxidant properties of yarrow (Achillea collina Beckerex Rchb.). Food Chemistry, 14: 204-211.

Hossain, Z., Lopez-Climent, M. F., Arbona, V., Perez-Clemente, R. M. and GomezCadenas, A. 2009. Modulation of the antioxidant system in citrus under waterlogging and subsequent drainage. J. Plant Physiol., 166(13): 1391-1404.

Kailash, C. M., Rao, S., Rao, S. K., Gontia, A.S. and Singh, S. K. 2014. Morphophysiological basis of waterlogging tolerance in pigeonpea [Cajanus cajan (L.) Millsp.]. Int. J. Agri. Environ. Biotech, 7(3): 455-463.

Kar, M. and Mishra, D. 1976. Catalase, Peroxidase and Polyphenoloxidase activities during rice leaf senescence. Plant Physiol., 57: 315-319.

Kulkarni, S. S. and Chavan, P. D. 2013. Influence of waterlogging on carbohydrate metabolism in ragi and rice roots. J. Stress Physiol. Biochem., 9(2): 199-205.

Kumutha, D., Ezhilmathi, K., Sairam, R. K., Srivastava, G. C., Deshmukh, P. S. and Meena, R. C. 2009. Waterlogging induced oxidative stress and antioxidant activity in pigeonpea genotypes. Biol. Planta, 53(1): 75-84.

Lin, K. H. R., Weng, C. C., Lo, H. F. and Chen, J. T. 2004. Study of the root antioxidative 
system of tomatoes and egg plants under waterlogged conditions. Plant Sci., 167: 355-365.

Ou, L. J., Dai, X. Z., Zhang, Z. Q. and Zou, X. $X$. 2011. Responses of pepper to waterlogging stress. Photosynthetica, 49: 339-345.

Polle, A. 2001. Dissecting the superoxide dismutase-ascorbate-glutathionepathway in chloroplasts by metabolic modeling: computer simulations as a step towards flux analysis. Plant Physiol., 126: 445462.

Rai, R. K., Srivastava, J. P. and Shahi, J. P. 2004. Effect of waterlogging on some biochemical parameters during early growth stages of maize. Indian J. Plant Physiol. 9: 65-68.

Sairam, R. K., Dharmar, K., Chinnusamy, V. and Meena, R. C. 2009. Waterlogging induced increase in sugar mobilization, fermentation, and related gene expression in the roots of mungbean (Vigna radiata L.). J. Plant Physiol., 166: 602-616.

Singh, V. P. 2010. Physiological and biochemical changes in pigeonpea (Cajanus cajan L.) genotypes to waterlogging stress at early stage. $\mathrm{Ph}$. D. Thesis, Banaras Hindu University, India.

Srivastava, J. P., Gangey, S. K. and Shahi, J. P. 2007. Waterlogging resistance in maize in relation to growth, mineral composition and some biochemical parameters. Indian J. of Plant Physiol., 12: 28-33.
Srivastava, J. P., Singh, P., Singh, V. P. and Bansal, R. 2010. Effect of waterlogging on carbon exchange rate, stomatal conductance and mineral nutrient status in maize and pigeonpea. Plant Stress, 4 (Special Issue 1): 95-99.

Tan, W., Liu, J., Dai, T., Jing, Q., Cao, W. and Jiang, D. 2008. Alterations in photosynthesis and antioxidant enzyme activity in winter wheat subjected to postanthesis waterlogging. Photosynthetica, 46(1): 21-27.

Tang, B., Shang-Zhong, X. U., Zou, X. L., Zheng, Y. L. and Qiu, F. Z. 2010. Changes of antioxidative enzymes and lipid peroxidation in leaves and roots of waterlogging-tolerant and waterloggingsensitive maize genotypes at seedling stage. Agri. Sci. China, 9(5): 651-66.

Teranishi, Y., Tanaka, A., Osumi, N. and Fukui, S. 1974. Catalase activity of hydrogen carbon utilizing condia yeast. Agri. Biol. Chem. 38: 1213-1216.

Thamodharan, G. and Arumugam Pillai, M. 2014. Role of antioxidative enzymes activity in salt stress and salinity screening in rice grown under in vitro condition. Int. J. Agri. Environ. And Biotech, 7(2): 261-268.

$\mathrm{Xu}$, F., Wang, X., Wu, Q., Zhang, X. and Wang, L. 2012. Physiological responses differences of different genotype sesames to flooding stress advance. J. Food Sci. Technol., 4(6): 352-356.

\section{How to cite this article:}

Dinesh Kumar Yadav and Srivastava J. P. 2017. Temporal Changes in Biochemical and Antioxidant Enzymes Activities in Maize (Zea mays L.) under Waterlogging Stress during Early Growth Stage. Int.J.Curr.Microbiol.App.Sci. 6(6): 351-362.

doi: https://doi.org/10.20546/ijcmas.2017.606.041 